\title{
Efficiency of Cartographic production for Decision-making
}

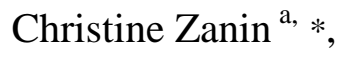 \\ ${ }^{a}$ Université Paris Diderot, UMR Géographie-Cités, France.Christine.zanin@univ-paris-diderot.fr \\ * Corresponding author
}

Keywords: Thematic maps, spatial planning, decision making, operational cartography, practionner's cartography work, survey

\begin{abstract}
:
The purpose of this communication is to analyze the link between cartographic production and decision-making in the field of spatial planning.

The mapping process, as a simple tool of the geographer and the production of neutral images of a territory, must be overcome. Cartography no longer aims to search for a (re)transcription, more or less objective, of reality, but constitutes at least an aid to spatial reflection, or even a central element for the construction of a territorial project. Any map, directly or indirectly, is a mental construction and a graphical expression. As an instrument for building or deconstructing knowledge and therefore power, Harley (1988) has long since shown that the cartographic image remains a multiple and evolving form of expression whose new faces allow new questions and new perspectives on the territory. Today, the abstraction of reality is no longer automatically that of the map or the political concept. The construction of an image via maps is no longer a portrait of a territory. The territory no longer precedes the map. It is now the map that precedes the territory; it is often the one that generates the territory. In this process, the design of the representation remains essential. The cartographer's eye, nourished by scientific innovation and artistic imagination, then has a real social utility, within an applied geography, an active and/or operational geography, to propose solutions not only for the representation of space but also for management and planning. All this is well known and disseminated. What remains to be done is the empirical and critical demonstration of the influence of cartographic design on a political and decision-making objective, and especially the way in which maps are chosen for a specific spatial action. The precarious balance resulting from the negotiations between political actors crystallizes into a cartographic production that is in turn banal or innovative, useful or useless for public action. Do political actors really use maps designed to support decision-making? And if so, which ones, and how?
\end{abstract}

Through questions of efficiency, aesthetics and practical and conceptual innovations, this research is looking for a way to move beyond the primitive stage of the "image maker" to rethink the link between the political decision-maker and the cartographer in the production of operational maps. This path is complex, but it must lead to evidence that is not as simple as one might think: the map is a powerful tool, constantly evolving, innovative but still misused and misunderstood. In this context, the objective is not to make the map a neutral object free of controversies but, on the contrary, one that effectively assumes the discourse of politics (the desired message is the one that is perceived) as well as one that shows the multiple facets of a reality to be shaped (the image produced helps to produce both reflection and discourse) and that allows discussion based on well-constructed images.

A first survey conducted on a panel of researchers and policy makers remained very illustrative of these questions. However, it has had the merit of establishing the first steps of further research to understand the mechanism at stake for an understanding and use of effective maps in the field of territorial policies. Thus, the objective of this survey is focused on the search for an effective and operational mapping for spatial planning action: finding operational solutions to deal with diversified and ever more abundant geographical information, relating to the questioning of territorial policies, addressing the process of exchanges between map designers and users, while working on its staging, understanding the mechanisms in place for understanding and using the maps produced in a decision-making framework. These questions are related to the desire to update the issues of perception and effectiveness of cartographic design for land use planning decisions.

The so-called "spatial planning" or "territorial decision-making aid" maps, which are increasingly present on the web, convey a vision of a territory built collectively by the various actors, but with an obvious normative priority. We get used to these representations without thinking that we could show others, perhaps more effective, more discordant, and more useful. Doing such an analysis helps to understand what is behind images and what needs to be changed to move towards greater visual effectiveness or political innovation. It is not a technical or software problem. For example, without textual explanations, European commission maps, like the ESPON ones, are not easy to understand and even less easy to implement in any territorial policy, so they require better contextualization and more appropriate legends. These maps are dominant and marginal; dominant because of the incredible fetishism surrounding these images, where often graphs or tables would be more useful and marginal because the resources allocated to it as a subject are derisory. The budget allocated to contracts focused on mapping achievements often weighs much less than that of many projects 
devoted to the production of composite indicators of poor interest. There is a profound error in the political effectiveness of spatial planning maps. We still need to demonstrate this.

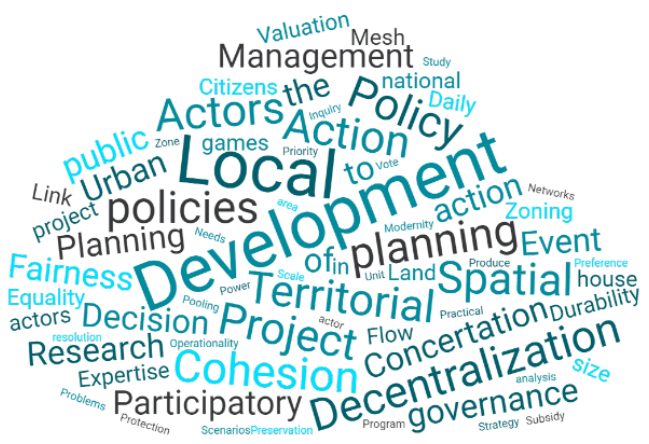

Figure 1. The Words of Spatial Planning (First survey, March 2018, 59 respondents)

In addition to this theoretical reflection, there is also the desire to address the process of exchanges between the designer and user of maps. It is in this context that the qualitative approach wishes to be developed. Indeed, engaging in a discussion with stakeholders in development policies as well as with designers and researchers around the issues of decision support mapping seems not only essential but indispensable when it comes to understanding the choices that are made. The first exploratory survey therefore needs to be refined and expanded. The new proposed survey aims to identify the place that the map occupies, compared to other tools, in a decision-making process relating to territorial action. We are also looking to understand at what stage(s) of the decision-making process and in what form(s) is the map used? Ultimately, the survey should help us to link the types of use of mapping to the profiles of territorial actors. The objective of this new survey would be to define (1) what is meant by territorial action and decision-making support in spatial planning when we are in an operational map production framework (see Fig. 1 a first result), (2) to understand how actors approach maps produced upstream to serve their actions, how they use and interpret them and finally, (3) what innovative maps should be produced for greater efficiency.

The proposed communication will report on the first results of this new survey of researchers and policy-makers.

ALBRECHTS L., 2001, "How to Proceed from Image and Discourse to Action: as applied to the Flamish Diamond". Urban studies, vol.38, N², pp.733-745

BAUDRILLARD J., 1981, Simulacres et simulation, PARIS GALILEE. p.10

BESSE J.M. (ss dir.), 2010, « Cartographies » et « Cheminements », in Les Carnets du Paysage N²0, Strabic.fr

DÜRH S., 2007, The Visual Language of Spatial Planning. Exploring cartographic representations for spatial planning in Europe. The RTPI Library series, Routledge, London, 196 p.

DÜRH S., 2015, Analysing cartographic representations in spatial planning, In: Silva, E.A.; Healey, P.; Harris, N. (ed.), The Routledge Handbook of Planning Research Methods, pp. 192-201

FALUDI A., 2002, The European Spatial Development Perspective (ESDP): an overview. Images of Europe tell their own story. European Spatial Planning, Faludi (ed.), Cambridge MA: Lincoln Institute of Land Policy, pp. 3-36

GABERELL S., DEBARBIEUX B., Mapping regions, framing projects. In: Geoforum, 2014, vol. 52, p.123-136.

HARLEY B., 1988, “Maps, Knowledge, and Power” in Cosgrove D., Daniels S. (eds) The iconography of landscape: essays on the symbolic representation, design and use of past environments, Cambridge: Cambridge University Press, pp. $277-312$

KUNZMANN K., 2016, “The Europeanization of Spatial Planning” in Regional Development and Spatial Planning in an Enlarged European Union, (Adam N., Eds), London, Routledge 304 p.

LAMBERT N., YSEBAERT R., ZANIN C., 2015, « Comprendre le territoire européen. Deux outils cartographiques à l'appui de la réflexion en aménagement du territoire ». L'information géographique, Colin pp. 45-54

ZANIN C., LAMBERT N., 2012, La multireprésentation cartographie. Exemple de l'Atlas interactif des régions européennes. Bulletin du CFC, n²13, pp.39-64. 